\title{
STUDY OF HYDROPHYTES IN SOME LENTIC WATER BODIES IN WEST BENGAL, INDIA
}

\author{
S.K. Das*, D. Biswas and S. Roy \\ *Waste Management Cell \\ West Bengal Pollution Control Board, Paribesh Bhawan, Bidhan Nagar, Block-LA \\ Salt Lake City, Sector-III, Kolkata-700098, India \\ e-mail: das_sanjibm@yahoo.com \\ Department of Engineering Physics \\ Calcutta Institute of Engineering and Management, Chandi Ghosh Road, Tollygunge, \\ Kolkata-700040, West Bengal, India.
}

\begin{abstract}
The physico-chemical characteristics of water, aquatic weeds and bank flora of three water reservoirs located in Krishnagar city (longitude $88^{0} 33^{\prime} \mathrm{E}$, latitude $23^{0} 24^{\prime} \mathrm{N}$ ), West Bengal, India, were studied for a period of 24 months. Altogether 13 genera of aquatic macrophytes belonging to 10 families, and 24 plant species (bank flora) belonging to 16 families were identified in the present investigation. The physico-chemical characteristic of pond water was found to be altered due to these aquatic plants. We have found a general relationship between trophic status of a water body and the aquatic plants present there. We have also found the alteration of water quality due to presence of various aquatic plants.
\end{abstract}

Key words: Physico-chemical characteristics, hydrophytes, macrophytes, bank flora, weeds.

\section{INTRODUCTION}

Evaluation of the biological community of a water body provides a sensitive and cost effective means of assessing stream condition (Willmer 2000). Pollution problem of inland water bodies, especially ponds has attracted the attention of researchers since long. Many workers have tried to establish relationship between trophic status of water bodies and aquatic plants (Wolverton and McDonald 1978). Agarkar et al. (1994) stated that eutrophic water bodies are characterized by the presence of aquatic plants (Brönmark and Hanson
2001). Kaul et al. (1980) opined that aquatic macrovegetation plays important role in maintaining ecological balance by nutrient recycling. Varshney (1981) and Oommachan et al. (1980) have designated certain aquatic plant species as pollution indicators. McVea and Boyd (1975) have reported that an aquatic plant alters the physico-chemical characteristics of pond water.

Krishnagar city is the district head quarter of Nadia, in the state of West Bengal, an eastern province of India. The sites are situated near the tropic of cancer situated at longitude $88^{0} 33^{\prime} \mathrm{E}$, 
latitude $23^{0} 24^{\prime} \mathrm{N}$. Water Reservoir-I (Hansadanga beel), Water Reservoir-II (Nowapara beel), and Water Reservoir-III (Kaji beel) were selected for the present study. All the water bodies are perennial. The general characteristics of water bodies are given in Table 1.

Table 1. General characteristics of three water bodies in the city of Krishnagar, West Bengal, India.

\begin{tabular}{llll}
\hline $\begin{array}{l}\text { Characte- } \\
\text { ristics }\end{array}$ & $\begin{array}{c}\text { Water } \\
\text { Reservoir- } \\
\text { I }\end{array}$ & $\begin{array}{c}\text { Water } \\
\text { Reservoir- } \\
\text { II }\end{array}$ & $\begin{array}{c}\text { Water } \\
\text { Reservoir- } \\
\text { III }\end{array}$ \\
\hline $\begin{array}{l}\text { Area (ha) } \\
\text { Sediment } \\
\text { (Colour) }\end{array}$ & 33.10 & 37.24 & 13.15 \\
Source of & Dark black & Dark black & Grey \\
Water & rains, & $\begin{array}{l}\text { Natural } \\
\text { rains, }\end{array}$ & Rains \\
& public & $\begin{array}{l}\text { public } \\
\text { sewage }\end{array}$ & \\
Sondition & Perennial & Perennial & Perennial \\
Maximum & 2.1 & 2.0 & 1.8 \\
Depth (m) & & & \\
\hline
\end{tabular}

The present investigation was aimed to study the physico-chemical characteristics of water, aquatic plants and bank vegetation of three ponds of Krishnagar (West Bengal) to find out impact of plants on water quality.

\section{MATERIALS AND METHODS}

Physico-chemical characteristics of water samples of all the three water bodies were analyzed between January 2002 and December 2004 using APHA (2002) and Trivedy et al. (1987). Aquatic vegetation was identified by consulting Fasseit (1957) and Gupta (1979).

Water samples were collected once a month from all the three water reservoirs for physicochemical analysis. Samplings were done between 9 to $11 \mathrm{am}$ from lentic zones at a depth of $5 \mathrm{~cm}$ from the surface. Water samples were collected in plastic containers (volume approx. 2 1). Temperature and $\mathrm{pH}$ were measured immediately after collection of the sample. Physico-chemical analyse for water temperature, turbidity, dissolved oxygen (DO), biological oxygen demand (BOD) initial, total dissolved solids (TDS), total alkalinity, total hardness calcium hardness, phosphate, nitrite and nitrate were performed in the laboratory on same day or within a week. Analyses of all parameters were done following the standard methods as out lined in APHA (2002). The monthly data were pooled together (Oct.Mar.=winter) and (Apr.-Sept.=summer). This divsion was made depending upon occurrence of macrophytes. The macrophytes started growing during April and reached peak in Jul.-Aug.; then gradually diminished after September. During winter, the macrophytes were greatly reduced.

\section{RESULTS AND DISCUSSION}

The physico-chemical characteristics of water samples of Hansadanga Beel (Water Reservoir-I), Nowapara beel (Water Reservoir-II) and Kaji beel (Water Reservoir-III) are presented in Table 2.

The aquatic macrophytes of all three water bodies studied during present investigation are listed in Table 3 along with their families. In all, 13 genera were identified, belonging to 10 families (Nostocaceae-1, Characeae-1, Cyperaceae-1, Hydrocharitaceae-3, Convolvulaceae-1, Myxophyceae-1, Pontederiaceae-1, Hallorrhagaceae-1, Nymphaeceae-2, and Alismataceae-1). In Water Reservoir-I and Water Reservoir-III Hydrilla verticillata dominated. In Water Reservoir-II Mycrocystis dominated over other weeds. In the present study Water ReservoirI was found covered fifty percent with macrophytes and water Reservoir-III was found covered twenty percent with macrophytes. 
Bank side flora (Table 4) of water bodies studied consisted of 24 species of plants belonging to 16 families (Mimosaceae-3, Annonaceae-2, Meliaceae-1, Bombaceae-1, Fabaceae-1, Asclepidaceae-1, Sapindaceae-1, Myrtaceae-1, Moraceae-3, Ulmaceae-1, Convolvulaceae-1, Anacardiaceae-1, Apocynaceae-4, Palmae-1, Caesalpiniaceae-1 and Rhamnaceae-1). Mangifera indica and Pithecellobium dulce were dominating plants on the banks of Water Reservoir 1. On banks of Water Reservoir-II, Azadirachta indica, Butea monosperma and Ficus bengalensis dominated. In Water Reservoir-III, only two plants i.e., Azadirachta indica and Mangifera indica found among bank side flora.

Table 2. Mean Physico-chemical characteristics of three water bodies in the city of Krishnagar, West Bengal, an eastern province of India ( $\mathrm{S}=$ Summer, W=Winter).

\begin{tabular}{|c|c|c|c|c|c|c|}
\hline \multirow[t]{2}{*}{ Parameter } & \multicolumn{2}{|c|}{ Water Reservoir-I } & \multicolumn{2}{|c|}{ Water Reservoir-II } & \multicolumn{2}{|c|}{ Water Reservoir-III } \\
\hline & $\mathbf{W}$ & S & W & S & $\mathbf{W}$ & $\mathbf{S}$ \\
\hline Water temperature $\left({ }^{0} \mathrm{C}\right)$ & $15 \pm 0.51$ & $28 \pm 0.53$ & $15.1 \pm 0.55$ & $28 \pm 0.58$ & $16 \pm 0.56$ & $29 \pm 0.65$ \\
\hline Turbidity & $49 \pm 7.8$ & $66 \pm 6.7$ & $25 \pm 7.1$ & $48 \pm 8.5$ & $39 \pm 8.3$ & $76 \pm 6.8$ \\
\hline $\mathrm{pH}$ & $8.71 \pm 0.16$ & $9.3 \pm 0.20$ & $8.55 \pm 0.18$ & $9.98 \pm 0.24$ & $8.69 \pm 0.15$ & $9.90 \pm 0.19$ \\
\hline Total Dissolved Solids (TDS) $\left(\mathrm{mg} \cdot \ell^{-1}\right)$ & $90 \pm 8.6$ & $130 \pm 7.8$ & $75 \pm 6.8$ & $139 \pm 8.1$ & $84 \pm 9.4$ & $106 \pm 7.7$ \\
\hline Dissolved Oxygen (DO) $\left(\mathrm{mg} \cdot \ell^{-1}\right)$ & $7.4 \pm 0.65$ & $7.2 \pm 0.71$ & $6.5 \pm 0.61$ & $7.0 \pm 0.66$ & $7.9 \pm 0.68$ & $6.5 \pm 0.63$ \\
\hline Biological Oxygen Demand (BOD) $\left(\mathrm{mg} . \ell^{-1}\right)$ & $2.6 \pm 0.43$ & $1.8 \pm 0.49$ & $1.2 \pm 0.39$ & $2.2 \pm 0.46$ & $2.8 \pm 0.55$ & $3.4 \pm 0.48$ \\
\hline Total Hardness $\left(\mathrm{mg} \cdot \ell^{-1}\right)$ & $99 \pm 9.8$ & $89 \pm 8.5$ & $110 \pm 8.6$ & $101 \pm 7.9$ & $139 \pm 9.2$ & $89 \pm 8.6$ \\
\hline Total Alkalinity $\left(\mathrm{mg} \cdot \ell^{-1}\right)$ & $109 \pm 13.6$ & $73 \pm 11.8$ & $77 \pm 12.6$ & $51 \pm 10.3$ & $84 \pm 10.4$ & $67 \pm 11.5$ \\
\hline Nitrite $\left(\mathrm{mg} \cdot \ell^{-1}\right)$ & Nil & $0.195 \pm 0.0068$ & Nil & $0.222 \pm$ & Nil & $0.220 \pm 0.0079$ \\
\hline Nitrate $\left(\mathrm{mg} \cdot \ell^{-1}\right)$ & $0.120 \pm 0.013$ & $0.092 \pm 0.009$ & $0.172 \pm 0.006$ & $0.061 \pm 0.003$ & $0.123 \pm 0.006$ & $0.103 \pm 0.008$ \\
\hline Phosphate (mg. $\left.\ell^{-1}\right)$ & $0.10 \pm 0.009$ & $0.18 \pm 0.006$ & $0.12 \pm 0.006$ & $0.20 \pm 0.015$ & $0.09 \pm 0.013$ & $0.16 \pm 0.089$ \\
\hline
\end{tabular}

Table 3. Aquatic weeds (micro and macro) of three water bodies in the city of Krishnagar, West Bengal,

\begin{tabular}{|c|c|c|c|c|}
\hline Species & Family & $\begin{array}{c}\text { Water } \\
\text { Reservoir-I }\end{array}$ & $\begin{array}{c}\text { Water } \\
\text { Reservoir-II }\end{array}$ & $\begin{array}{c}\text { Water } \\
\text { Reservoir-III }\end{array}$ \\
\hline Chara sp. & Characeae & + & - & + \\
\hline Cyperus dilutus & Cyperaceae & + & - & - \\
\hline Ottelia alismoides L. & Hydrocharitaceae & + & - & - \\
\hline Vallisnaria spiralis L. & Hydrocharitaceae & + & - & + \\
\hline Ipomea aquatica Forsk & Convolvulaceae & + & - & - \\
\hline Microcystis sp. & Myxophyceae & + & + & - \\
\hline Monochoria hastate Solms & Pontederiaceae & + & - & - \\
\hline Sagittaria guavanensis & Alismataceae & + & - & - \\
\hline
\end{tabular}

Area covered by Weed (approximate) $25 \%--$

Biomass of Weed (Dry weight) $71.0 \mathrm{~g} / \mathrm{cm}^{2}, 1.25 \mathrm{~g} / \mathrm{cm}^{2}, 0.50 \mathrm{~g} / \mathrm{cm}^{2}$ in Reservoirs I, II and III.

Dominated Weed: Hydrilla verticillata at Water Reservoir-I and Water Reservoir-III; Microcystis sp. at Water Reservoir-II

$+=$ Denotes presence of weed; $-=$ Denotes absence of weed 
Table 4. Bank side flora of three water bodies in the city of Krishnagar, West Bengal, India.

\begin{tabular}{|c|c|c|c|c|}
\hline Species & Family & $\begin{array}{c}\text { Water } \\
\text { Reservoir-I }\end{array}$ & $\begin{array}{c}\text { Water } \\
\text { Reservoir-II }\end{array}$ & $\begin{array}{c}\text { Water } \\
\text { Reservoir-III }\end{array}$ \\
\hline Acacia nilotica Var. & Mimosaceae & + & + & - \\
\hline Albizzia procera. Benth. & Mimosaceae & + & - & - \\
\hline Annona reticulate Linn. & Annonaceae & + & - & - \\
\hline Annona squamosa Linn. & Annonaceae & + & + & - \\
\hline Azadirachta indica Juss. & Meliaceae & + & + & + \\
\hline Bombax ceiba Linn. & Bombaceae & + & - & - \\
\hline Butea monosperma Kunt. & Fabaceae & + & - & - \\
\hline Calotropis procera $\mathrm{Br}$. & Asclepidaceae & + & - & - \\
\hline Dononaea viscose Linn. & Sapindaceae & + & - & - \\
\hline Eucalyptus citriodora Hook & Myrtaceae & + & - & - \\
\hline Ficus bengalensis Linn. & Moraceae & + & - & - \\
\hline Ficus racemosa Linn. & Moraceae & + & - & - \\
\hline Ficus religiosa Linn. & Moraceae & + & - & - \\
\hline Holoptelea integrifolia Plan. & Ulmaceae & + & - & - \\
\hline Ipomoea fistulosa Choisy & Convolvulaceae & + & + & - \\
\hline Mangifera indica Linn. & Ancardiaceae & + & + & + \\
\hline Nerium indium Mill. & Apocynaceae & + & - & - \\
\hline Pithecellobium dulce Benth. & Mimosaceae & + & + & - \\
\hline Plumeria rubra Sant. & Apocynaceae & + & - & - \\
\hline Phoenix sylvestris Roxb. & Palmae & + & - & - \\
\hline Tabernaemontana divaricata $\mathrm{Br}$. & Apocynaceae & + & - & - \\
\hline Tamarindus indica Linn. & Caesalpiniaceae & + & + & - \\
\hline Thevetia peruviana Schum & Apocynaceae & + & + & - \\
\hline Zizyphus jujube Linn. & Rhamnaceae & + & - & - \\
\hline
\end{tabular}

Total number of plants 30, 18, 03 around Reservoirs I, II and III.

Dominated plants: Mangifera indica, Pithecellobium dulce around Water Reservoir-I;

Azadirachta indica, Ficus bengalensis around Water Reservoir-II;

Annona squamosa around Water Reservoir-III.

$+=$ Denotes presence of plant; $-=$ Denotes absence of plant.

Macrovegetation in and around the water body plays important role in determining its hydrobiological characteristics. Normally lakes and other surface waters are classified into oligotrophic and eutrophic. According to Agarkar et al. (1994) eutrophic conditions can be generally

ECOPRINT VOL 16, 2009 characterized by increasing number of aquatic plants in water body that can cause further eutrophication.

Kaul et al. (1980) have stated that the macrovegetation is useful in maintaining ecological balance by deriving nutrients from the 
water in benthic zone. Varshney (1981) have pointed out that certain aquatic plants like Lemna, Eichhornia, Utricularia, Myriophyllum, Nuphar and Potamogeton can be used as pollution indicator. Oommachan et al. (1980) also reported Potamogeton pectintus, P. crispus, Utricularia sp. Trapa bispionsa, Marsilea polygonum and Cyperus salopecuroides as pollution indicator. In the present investigation Myriophyllum was found only in Water reservoir-I.

McVea and Boyd (1975) stated that aquatic plants change the quality of water by lowering the temperature, $\mathrm{pH}$, bicarbonates, alkalinity and dissolved oxygen and increase the free $\mathrm{CO}_{2}, \mathrm{BOD}$ and nutrient levels. In the present study this statement was found to be true except for alkalinity which has comparatively higher value.

\section{CONCLUSION}

In the present investigation we found considerable macrovegetation when compared with water reservoir-II, reservoir-I, and water reservoirIII. The increased number of macro vegetation indicates that the water quality of these reservoirs is going towards eutrophied condition.

\section{REFERENCES}

Agarkar, M.S., H.K. Goswami, S. Kaushik, S.N. Mishra, A.K. Bajpai and U.S. Sharma. 1994. Biology, conservation and management of Bhoj wetland 1. Upperlake Ecosystem in Bhopal. Bionature 14 (2):1-119.

APHA. 2002. Standard Methods for the Examination of Water and Waste Waters $\left(21^{\text {st }}\right.$ edn.), American Water Works Association (AWWA), Water Pollution Control Federation (WPCF) and American Public Health Association (APHA) Washington DC, USA.

Brönmark, C. and L.A. Hansson. 2001. The Biology of Lakes and Ponds. Oxford University Press, UK.
Fasseit, N.C. 1957. A Manual of Aquatic Plants. The University of Wisconsin Press, Madison, USA.

Gupta, O.P. 1979. Aquatic Weeds: Their Manace and Control. Today and Tomorrow's Printers and Publisher, New Delhi, India.

Kaul, V., A.K. Pandit and D.N. Foteder. 1980. Management of wetland ecosystem and as wildlife habitats in Kashmir. In: Proc. Int. Seminar Management of Environment. (ed.) Patel, B. Bhabha Atomic Research Center, Bombay, India.

McVea, C. and C.E. Boyd. 1975. Effect of water hyacinth cover on water chemistry, phytoplankton and fish in ponds. J. Environ. Qual. 4:375-378.

Oommachan, M., A. Hafeez, S. Khan and S. Khan. 1980. Studies on the vegetation of marshes ponds and lakes in Bhopal. J. Sc. Res. 2(2):141-143.

Trivedy, R.K., P.K. Goel and C.L. Trisal. 1987. Practical Methods in Ecology and Environmental Science. Environmental Publications, Karad, India.

Varshney, C.K. 1981. Macrophytes as indicators of water quality. In: WHO Workshop on Biological Indicators and Indices of Environment Pollution, Hyderabad, Indian Cent. Ed. Prood. Cont. Water. Poll., Osmnia University.

Willmer, P., G. Stone and I. Jhonston. 2000. Environmental Physiology of Animals. Blackwell Science Ltd., USA.

Wolverton, B.C. and R.C. McDonald. 1978. Water hyacinth absorption rates of Lead, Mercury and Cadmium. Hydrobiologia 22:132-135. 